\title{
Inheritance of resistance to Pepper yellow mosaic virus in Capsicum baccatum var. pendulum
}

\author{
C.S. Bento, R. Rodrigues, L.S.A. Gonçalves, H.S. Oliveira, \\ M.H. Santos, M.C. Pontes and C.P. Sudré \\ Universidade Estadual do Norte Fluminense Darcy Ribeiro, \\ Campos dos Goytacazes, RJ, Brasil \\ Corresponding author: R. Rodrigues \\ E-mail: rosana@uenf.br
}

Genet. Mol. Res. 12 (2): 1074-1082 (2013)

Received May 7, 2012

Accepted July 11, 2012

Published April 10, 2013

DOI http://dx.doi.org/10.4238/2013.April.10.3

\begin{abstract}
We investigated inheritance of resistance to Pepper yellow mosaic virus (PepYMV) in Capsicum baccatum var. pendulum accessions UENF 1616 (susceptible) crossed with UENF 1732 (resistant). Plants from generations $\mathrm{P}_{1}, \mathrm{P}_{2}, \mathrm{~F}_{1}, \mathrm{~F}_{2}, \mathrm{BC}_{1: 1}$, and $\mathrm{BC}_{1: 2}$ were inoculated and the symptoms were evaluated for 25 days. Subsequently, an area under the disease progress curve was calculated and subjected to generation means analysis. Only the average and epistatic effects were significant. The broad and narrow sense heritability estimates were 35.52 and $21.79 \%$, respectively. The estimate of the minimum number of genes that control resistance was 7 , indicating that resistance is polygenic and complex. Thus, methods to produce segregant populations that advocate selection in more advanced generations would be the most appropriate to produce chili pepper cultivars resistant to PepYMV.
\end{abstract}

Key words: Chili peppers; Genetic control of disease resistance; Genetic parameters; Heritability; Mean generation analysis 


\section{INTRODUCTION}

The genus Capsicum, which includes sweet and chili peppers, originates from the Americas, and is widespread throughout the world. This genus comprises 31 species, but only 5 are grown for commercial purposes: $C$. annuum L., C. baccatum L., C. chinense Jacq., $C$. frutescens L., and C. pubescens Ruiz \& Pav. (Pickersgill, 1997; Moscone et al., 2007).

Sweet and chili peppers are characterized by their broad versatility of applications. They can be used for culinary, industrial, medicinal, and ornamental purposes (Sudré et al., 2010; Rêgo et al., 2011). Furthermore, their cultivation favors increased income for small farms and the establishment of workers in rural areas, mainly due to extensive use of manual labor at harvest time (Moura et al., 2010; Sudré et al., 2010; Ferrão et al., 2011).

Despite recent technological advances in sweet and chili pepper production systems, pathogens are considered a major limitation to high fruit yield and fruit quality (Bento et al., 2009). Anthracnose (Colletotrichum gloeosporioides), vascular wilt (Phytophthora capsici), bacterial spot (Xanthomonas spp), and viral infections caused by Potato virus Y (PVY), Pepper yellow mosaic virus (PepYMV), Tobacco mosaic virus, Cucumber mosaic virus, and tospoviruses stand out among the various diseases reported in Brazil (Inoue-Nagata et al., 2002; Carmo et al., 2006).

PepYMV prevails in the main sweet and chili pepper national-producing area and is considered, along with vascular wilt, a priority in Brazilian Capsicum breeding programs (Ávila et al., 2004; Maciel-Zambolim et al., 2004; Nascimento et al., 2007; Bento et al., 2009; Moura et al., 2011). PepYMV and PVY cause identical symptoms and these two viruses are serologically related, although they may be differentiated by some tests, such as indirect ELISA (Truta et al., 2004). The symptoms caused by PepYMV in Capsicum include curling leaves, mosaic development with yellowish green shade, general reduction in the size of plants and fruits, and fruit deformation (Carmo et al., 2006).

The most efficient way to control viral diseases is the use of resistant varieties. With regard to Potyvirus, different mechanisms of action to prevent viral replication and movement have been associated with resistance to the virus (Janzac et al., 2009). These different mechanisms have different genetic controls, involving recessive and dominant genes. In the first case, monogenic recessive resistance conferred by genes $p v r 1, p v r 2, p v r 3$, or $p v r 5$ is the result of a passive mechanism in which the absence of interaction between the plant resistance factor and virus virulence factor prevents the virus from completing its replication cycle. On the other hand, the dominant resistance, represented by the presence of genes Pvr4, Pvr6 or Pvr7, is based on the gene-to-gene model (Caranta et al., 1999; Grub et al., 2000).

Most of these alleles confer resistance to two or more species of Potyvirus. For example, the dominant allele Pvr4, identified in C. annuum cv. Criollo de Morelos 334, confers resistance to PVY, PepMoV, PTV, PepSMV, and PepYMV, often used in cultivars of sweet and chili peppers due to their wide activity (Janzac et al., 2009; Moura et al., 2011).

However, Gioria et al. (2009) found a break in resistance to PepYMV in commercial plantations with cultivar Magali R, bearer of the gene Pvr 4, in the State of São Paulo, Brazil. Thus, the search for new sources of resistance to PepYMV and subsequent determination of genetic control are essential for breeding programs aimed at releasing sweet and chili pepper cultivars (Juhász et al., 2008).

Due to the wide genetic variability of the genus Capsicum, it is possible to search and use germplasm as a source of resistance to obtain cultivars resistant to Potyvirus species. 
Bento et al. (2009) evaluated 127 accessions of Capsicum ssp present in the germplasm collection of the Universidade Estadual do Norte Fluminense Darcy Ribeiro (UENF) for resistance to PepYMV. Nine of these were identified as resistant, where 7 were accessions of the species C. chinense and two of the species $C$ baccatum var. pendulum. Potyvirus resistance in C. chinense has already been described in the literature (Boiteux and Pessoa, 1994), but this is the first report on resistance in C. baccatum var. pendulum, a species whose fruits are promising for fresh consumption, for use in sauces and salads, in the food industry (Gonçalves et al., 2011), and in the pharmaceutical industry (Zimmer et al., 2012). Despite all these potential uses attributed to C. baccatum var. pendulum, little information is available in the literature regarding its genetics and breeding.

This study aimed to evaluate the genetic basis of resistance of C. baccatum var. pendulum to the Potyvirus PepYMV.

\section{MATERIAL AND METHODS}

\section{Plant material}

The first stage of this study was hybridization, to obtain seeds from the $\mathrm{F}_{1}$ hybrid, from $\mathrm{F}_{2}$ segregating generations and backcrosses $\left(\mathrm{BC}_{1: 1}\right.$ and $\left.\mathrm{BC}_{1: 2}\right)$. The $\mathrm{F}_{1}$ hybrid seeds were obtained by the crossing between the accession UENF 1616, susceptible to PepYMV, and the resistant accession UENF 1732. The hybridizations were carried out in a greenhouse located at the Universidade Estadual do Norte Darcy Ribeiro (UENF), in Campos dos Goytacazes, RJ, Brazil.

After obtaining the seeds for the 6 generations, the parents $\left(\mathrm{P}_{1}\right.$ and $\left.\mathrm{P}_{2}\right)$, the hybrid $\mathrm{F}_{1}$, the segregating generation $\mathrm{F}_{2}$ and the backcrosses $\left(\mathrm{BC}_{1: 1}\right.$ and $\left.\mathrm{BC}_{1: 2}\right)$, the plants were sown in

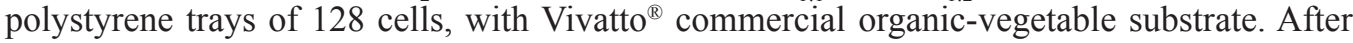
the emergence of 2 pairs of leaves, the seedlings were transplanted individually to $500-\mathrm{mL}$ plastic cups containing a mixture of substrate and soil at a 2:1 ratio and cultivated in a growth chamber, with controlled temperature, photoperiod and humidity $\left(25^{\circ} \mathrm{C}, 12 \mathrm{~h}\right.$ and $80 \%$, respectively). Twenty plants were grown for each of the parents and the $\mathrm{F}_{1}$ hybrid, $200 \mathrm{~F}_{2}$ plants and 50 plants in each backcross generation $\left(\mathrm{BC}_{1: 1}\right.$ and $\left.\mathrm{BC}_{1: 2}\right)$. Two healthy plants of each parental generation and 20 plants of the cultivar Criollo de Morelos were used as a negative control, while 20 plants of the cultivar Ikeda, susceptible to PepYMV and inoculated with the virus, were used as positive control.

\section{Inoculation procedure}

Plants of Nicotiana debneyi infected with isolate 3 PepYMV were used as the inoculum source. The isolate was obtained from pepper plants collected in the field in the municipality of Igarapé, State of Minas Gerais (Truta et al., 2004), provided by Professor Francisco Murilo Zerbini Junior (Universidade Federal de Viçosa). The inoculation was carried out via plant extract in $0.05 \mathrm{M}$ potassium phosphate buffer, $\mathrm{pH} 7.2$, containing $0.01 \%$ sodium sulfate, using carborundum (600 mesh) as abrasive (Truta et al., 2004). Plants were inoculated at the stage of 3 to 4 leaves and reinoculated $48 \mathrm{~h}$ after the first inoculation to avoid the incidence of escape. The youngest fully expanded leaves were inoculated with virus inoculum. The controls were inoculated only with the buffer solution and the abrasive. The evaluation was performed 
every 2 days, from the 15 th day after the first inoculation, when symptoms began to appear. Visual assessment was carried out using a rating scale proposed by Bento et al. (2009): score $1=$ symptomless plants; 2 = plants showing slight symptoms (up to $25 \%$ of the leaf area with small mosaic dots); 3 = plants showing moderate symptoms (up to $50 \%$ of the leaf area with mosaic); $4=$ strong symptoms (up to $75 \%$ of the leaf area with mosaic); and $5=$ severe symptoms $(100 \%$ of the leaf area with mosaic, leaves displaying swelling and curling, and reduction of leaf area).

\section{Statistical analysis}

The grades achieved during the days of evaluation of the 6 generations $\left(\mathrm{P}_{1}, \mathrm{P}_{2}, \mathrm{~F}_{1}\right.$, $\mathrm{F}_{2}, \mathrm{BC}_{1: 1}$, and $\mathrm{BC}_{1: 2}$ ) inoculated with PepYMV were used to calculate the area under the disease progress curve (AUDPC), according to the equation suggested by Campbell and Madden (1990). Later, the AUDPC data were subjected to the analysis of the generation means, proposed by Mather and Jinks (1984). The statistical analysis was performed with the aid of the Genes software system (Cruz, 2006).

\section{RESULTS AND DISCUSSION}

It was possible to visualize the symptoms of virus infection at various stages of development in the plant, confirming the virulence of isolate 3 of PepYMV used for the inoculation of generations $\mathrm{P}_{1}, \mathrm{P}_{2}, \mathrm{~F}_{1}, \mathrm{~F}_{2}, \mathrm{BC}_{1: 1}$ and $\mathrm{BC}_{1: 2}$ of $C$. baccatum var. pendulum. It was observed that $58.82 \%$ of the individuals in the $\mathrm{F}_{1}$ hybrids reached scale $1,17.65 \%$, scale 2 , and $23.53 \%$, scale 3. In the $\mathrm{F}_{2}$ generation, a wide segregation of individuals was observed for this trait. As noted in these results, more than one gene is involved in the control of virus resistance in plants of these generations.

The data obtained for AUDPC were used to estimate genetic parameters and analyze the means of the generations. Environmental variance accounted for $64.41 \%$ of the total phenotypic variance, and $35.59 \%$ was due to genetic causes. Of the latter, $61.28 \%$ was related to the additive variance, which is the inheritable fraction of the genotypic variance that enabled the successful selection of segregating populations, and $38.72 \%$ to the variance of dominance related to the intra-allelic interaction, i.e., it is a non-heritable fraction of the genotypic variance (Cruz and Carneiro, 2003) (Table 1).

Table 1. Estimates of the genetic parameters obtained from the values of AUDPC for the assessment of resistance to Pepper yellow mosaic virus (PepYMV), evaluated in plants of generations $\mathrm{P}_{1}, \mathrm{P}_{2}, \mathrm{~F}_{1}, \mathrm{~F}_{2}, \mathrm{BC}_{1: 1}$, and $\mathrm{BC}_{1: 2}$ from the crossing between UENF 1616 and UENF 1732 of Capsicum baccatum var. pendulum.

\begin{tabular}{lc}
\hline Genetic parameters & Resistance to PepYMV \\
\hline Phenotypic variation $\left(\sigma_{\mathrm{p}}^{2}\right)$ & 13.57 \\
Environmental variance $\left(\sigma^{2}\right)$ & 8.75 \\
Genotypic variance $\left(\sigma_{\mathrm{e}}^{2}\right)$ & 4.83 \\
Additive variance $\left(\sigma_{\mathrm{a}}^{2}{ }_{\mathrm{g}}\right.$ & 2.96 \\
Variance of dominance $\left(\sigma_{\mathrm{d}}^{2}\right)$ & 1.87 \\
Broad-sense heritability $\left(\mathrm{h}^{2}\right)$ & 35.52 \\
Narrow-sense heritability $\left(\mathrm{h}_{\mathrm{n}}^{2}\right)$ & 21.79 \\
Average degree of dominance $(\mathrm{ADD})$ & 1.12 \\
Minimum number of genes $(\eta)$ & 7.00 \\
Generation coefficient of genotypic determination $\left(\mathrm{H}^{2}\right)$ & - \\
\hline
\end{tabular}


Broad-sense heritability was estimated at $35.52 \%$, while in the narrow sense, the estimate was $21.79 \%$. These figures show that about $35.52 \%$ of the total variance in the $\mathrm{F}_{2}$ population resulted from genetic causes. Of these, approximately $22 \%$ are attributed to genetic causes of additive nature, which is fixed over the inbred generations. Low narrow sense heritability indicates that selection in early generations should not be performed because it is not possible to be sure that the superior phenotypes observed correspond to the desired genotypes. In this case, a single-seed descent is recommended. It allows a rapid advance of generations for later selection of genotypes (Allard, 1971; Fehr, 1987).

Heritability values related to diseases have been quite variable, as observed in some studies, such as those also on solanaceous plants carried out by Riva et al. (2004) and Juhász et al. (2008). Broad-sense heritability for resistance to bacterial spot in C. annuum L. was estimated at 82.50 and $85.58 \%$, respectively, when two resistance components (number of pustules on leaves and rating scale) were tested. On the other hand, narrow sense heritability was low, with values of $50.77 \%$ for number of pustules and $45.63 \%$ for the rating scale (Riva et al., 2004). Juhász et al. (2008) found broad-sense heritability of $99.22 \%$ for resistance to PepYMV in wild tomato accessions in generations from the crossing between "Santa Clara" and BGH 6902. Ferreira et al. $(2003,2004)$ studied resistance to common bacterial blight in beans and found narrow sense heritability values of $80 \%$ in $\mathrm{F}_{6}$ and $88 \%$ in $\mathrm{F}_{7}$, which contrasted with the narrow sense heritability value of $26.85 \%$ observed in the $\mathrm{F}_{3}$ generation from the same cross between HAB52 and BAC6. It is necessary to consider that heritability is a parameter that depends on the population studied and the environment to which the individuals were submitted (Ramalho et al., 1993).

In this study, the average degree of dominance was 1.12 , which shows overdominance type of gene action. In the tomato-PepYMV pathosystem, Juhász et al. (2008) observed complete dominance while studying virus resistance in generations from interspecific crosses between cultivated and wild tomato.

The estimated minimum number of genes that control resistance to PepYMV in $C$. baccatum was 7, indicating that resistance in this population is polygenic and confirming the results obtained for narrow sense heritability that selection of superior individuals must be made in advanced generations, due to environmental influence. A marker based on polymerase chain reaction, using cleaved amplified polymorphic sequence is available for identification of the Pvr4 gene from C. annuum (Caranta et al., 1999), and it could be used to select resistant genotypes in a marker-assisted selection procedure. However, our results indicate more than one gene controlling resistance. Even though $C$. baccatum UENF 1732 carries the Pvr4 allele for resistance to PepYMV, the use of this marker alone would not be enough to ensure the identification of the resistant individuals in the population. Virus resistance with polygenic or oligogenic control has also been found by other authors. Juhász et al. (2008) found that resistance to PepYMV in tomato is controlled by more than one gene. Bezerra Jr. et al. (2006) studied the inheritance of resistance to Watermelon mosaic virus in watermelon and found that resistance to this virus may be considered polygenic with indication of complete dominance. $\mathrm{Xu}$ et al. (2004) observed that resistance to mosaic virus in watermelon is controlled by at least two other recessive genes.

The genetic parameter with the highest value was the average (11.95) followed by dominance effect (4.48). The parameter related to additivity showed a negative estimate. According to Lobo et al. (2005), this results in an additive effect because the parent and its re- 
spective backcross do not always refer to the genotype with the highest character expression. The $t$-test was significant at $1 \%$ probability only for the average, while the additive-dominant and dominant-dominant epistatic effects were significant at 5\% (Table 2). By the non-orthogonal decomposition of the sum of squares, in the complete model (Table 3), it was found that the genetic effect related to average was the most important to control the resistance character, with a determination coefficient of $82.01 \%$, followed by the epistatic effects of dominantdominant $(9.40 \%)$ and additive-dominant $(6.37 \%)$, indicating the importance of these effects in controlling resistance to PepYMV in the generations studied.

Table 2. Estimate of genetic effects and significance test of the null hypothesis of genetic parameters for resistance to PepYMV in the complete model ( $\mathrm{m}, \mathrm{a}, \mathrm{d}$, aa, ad, dd), evaluated in plants of generations $\mathrm{P}_{1}, \mathrm{P}_{2}, \mathrm{~F}_{1}, \mathrm{~F}_{2}$, $\mathrm{BC}_{1: 1}$, and $\mathrm{BC}_{1: 2}$ from the crossing between UENF 1616 and UENF 1732 of Capsicum baccatum var. pendulum.

\begin{tabular}{lccc}
\hline Parameters & & AUDPC & $t$ \\
\cline { 2 - 4 } & Estimative & Variance & $6.14^{* *}$ \\
\hline $\mathrm{m}$ & 11.95 & 3.79 & $-0.08^{\text {ns }}$ \\
$\mathrm{a}$ & -0.05 & 0.35 & $0.84^{\text {ns }}$ \\
$\mathrm{d}$ & 4.48 & 28.51 & $-0.56^{\text {ns }}$ \\
aa & -1.03 & 3.44 & $-1.71^{*}$ \\
ad & -3.28 & 3.68 & $-2.08^{*}$ \\
dd & -7.40 & 12.70 & . \\
\hline
\end{tabular}

AUDPC $=$ area under the disease progress curve. ${ }^{* *},{ }^{*}$ Significant at 1 and $5 \%$ probability, respectively, by the $t$-test; ns $=$ non-significant.

Table 3. Non-orthogonal decomposition of the sum of squares of parameters set for resistance to PepYMV, in complete model ( $\mathrm{m}$, a, d, aa, ad, dd), measured in plants of generations $\mathrm{P}_{1}, \mathrm{P}_{2}, \mathrm{~F}_{1}, \mathrm{~F}_{2}, \mathrm{BC}_{1: 1}$, and $\mathrm{BC}_{1: 2}$ from the crossing between UENF 1616 and UENF 1732 of Capsicum baccatum var. pendulum.

\begin{tabular}{lcc}
\hline Parameters & & \\
\cline { 2 - 3 } & Sum of squares & AUDPC \\
\hline $\mathrm{m} / \mathrm{a}, \mathrm{d}, \mathrm{aa}, \mathrm{ad}, \mathrm{dd}$ & 82.01 \\
$\mathrm{a} / \mathrm{m}, \mathrm{d}, \mathrm{a}, \mathrm{ad}, \mathrm{dd}$ & 37.67 & 0.01 \\
$\mathrm{~d} / \mathrm{m}, \mathrm{a}, \mathrm{a}, \mathrm{ad}, \mathrm{dd}$ & 0.006 & 1.53 \\
$\mathrm{aa} / \mathrm{m}, \mathrm{a}, \mathrm{d}, \mathrm{ad}, \mathrm{dd}$ & 0.70 & 0.67 \\
$\mathrm{ad} / \mathrm{m}, \mathrm{a}, \mathrm{d}, \mathrm{aa}, \mathrm{dd}$ & 0.31 & 6.37 \\
$\mathrm{dd} / \mathrm{m}, \mathrm{a}, \mathrm{d}, \mathrm{aa}, \mathrm{ad}$ & 2.93 & 9.40 \\
\hline
\end{tabular}

AUDPC $=$ area under the disease progress curve.

Considering the observed and expected averages, the complete model with a maximum correlation coefficient $(\mathrm{r}=1.0)$ proved its adequacy in explaining the effects involved in controlling resistance to PepYMV, and its variability. The complete model also explained the data obtained for the reaction to bacterial spot in sweet pepper, demonstrating the importance of epistatic effects in controlling this trait (Juhász et al., 2008). Besides, Xu et al. (2004) assessed resistance in watermelon to Zucchini yellow mosaic virus and to mosaic virus and concluded that the complete model was sufficient to explain the parameters evaluated in the study on inheritance of resistance to these two pathogens.

When tested, the additive-dominant model (Table 4) demonstrated again that the most important parameter was the average (12.94). The $t$-test showed significance for all parameters (m, a, d). It was observed that the additive effects (obtained in the complete model and in the 
additive-dominant model), as well as the effect of dominance in the additive-dominant model, achieved negative variances, confirming the study of Lobo et al. (2005). In the additivedominant model, a determination coefficient of $98.30 \%$ was recorded to explain the results through the average (Table 5). The correlation coefficient calculated, $r=0.367$, showed that the additive-dominant model was not efficient in explaining the results obtained, because this model does not consider the epistatic effects that control this trait.

\begin{tabular}{|c|c|c|c|}
\hline \multirow[t]{2}{*}{ Parameters } & \multicolumn{3}{|c|}{ AUDPC } \\
\hline & Estimative & Variance & $t$ \\
\hline $\mathrm{m}$ & 12.94 & 0.20 & $29.03^{*}$ \\
\hline a & -0.95 & 0.21 & $-2.07^{*}$ \\
\hline d & -2.48 & 0.60 & $-3.20^{* *}$ \\
\hline
\end{tabular}

Table 5. Non-orthogonal decomposition of the sum of squares of parameters set for resistance to PepYMV, in additive-dominant model ( $\mathrm{m}$, a, d), evaluated in plants from generations $\mathrm{P}_{1}, \mathrm{P}_{2}, \mathrm{~F}_{1}, \mathrm{~F}_{2}, \mathrm{BC}_{1: 1}$, and $\mathrm{BC}_{1: 2}$ from the crossing between UENF 1616 and UENF 1732 of Capsicum baccatum var. pendulum.

\begin{tabular}{lrr}
\hline Parameters & & AUDPC \\
\cline { 2 - 3 } & Sum of squares & $\mathrm{R}^{2}(\%)$ \\
\hline m/a, d, aa, ad, dd & 842.52 & 98.30 \\
a/m, d, aa, ad, dd & 4.30 & 0.50 \\
d/m, a, aa, ad, dd & 10.26 & 1.20 \\
\hline
\end{tabular}

AUDPC $=$ area under the disease progress curve.

While studying the genetic basis of resistance of a wild tomato accession to Pepper yellow mosaic, caused by PepYMV, Juhász et al. (2008) concluded that the additive-dominant model was sufficient to explain the gene effects involved in the inheritance of resistance, indicating that the epistatic effects were not important in controlling resistance. A similar result was obtained by Bezerra Jr. et al. (2006), who determined that the additive-dominant model was adequate to explain the control of watermelon resistance to Watermelon mosaic virus without including epistatic interactions. Lobo et al. (2005) also identified the adequacy of the additive-dominant model in the explanation of the parameters studied in the inheritance of resistance to bacterial spot in tomato.

In contrast to what has been reported in the literature for PepYMV resistance in other Capsicum species, the inheritance of this character in Capsicum baccatum var. pendulum is polygenic and complex. Nonetheless, it should be noted that the identification of new sources of resistance and also working with resistance genes are important challenges for plant breeders and geneticists for a clearer understanding of the plant-pathogen interaction to achieve a more durable resistance to diseases. Thus, in the present research, methods for conducting segregant populations that allow selection in more advanced generations are best suited for the continuation of the breeding program aimed at obtaining pepper cultivars resistant to PepYMV. 


\section{ACKNOWLEDGMENTS}

Research supported by Fundação Carlos Chagas Filho de Amparo à Pesquisa do Estado do Rio de Janeiro (FAPERJ). C. dos S. Bento was awarded a doctoral scholarship from FAPERJ. We thank Professor Dr. Francisco Murilo Zerbini Jr. from the Federal University of Viçosa for providing the isolate of Pepper yellow mosaic virus.

\section{REFERENCES}

Allard RW (1971). Princípios do Melhoramento Genético das Plantas. Edgard Blucher, Rio de Janeiro.

Ávila AC, Inoue-Nagata AK, Costa H, Boiteux LS, et al. (2004). Ocorrência de viroses em tomate e pimentão na região serrana do Estado do Espírito Santo. Hortic. Bras. 22: 655-658.

Bento CS, Rodrigues R, Zerbini F Jr and Sudré CP (2009). Sources of resistance against the Pepper yellow mosaic virus in chili pepper. Hortic. Bras. 27: 196-201.

Bezerra JEA Jr, Maluf WR, Figueira AR and Barguil BM (2006). Herança da resistência ao Watermelon mosaic virus em melancia (Citrullus lanatus L.). Fitopatol. Bras. 3: 302-305.

Boiteux LS and Pessoa HBSV (1994). Additional sources of resistance to an isolate PVYm in Capsicum germplasm. Fitopatol. Bras. 19: 291.

Campbell CL and Madden LV (1990). Introduction to Plant Disease Epidemiology. John Wiley \& Sons, New York.

Caranta C, Thabuis A and Palloix A (1999). Development of a CAPS marker for the Pvr4 locus: a tool for pyramiding potyvirus resistance genes in pepper. Genome 42: 1111-1116.

Carmo MGF, Zerbini FM Jr and Maffia LA (2006). Principais doenças da cultura da pimenta. Informe Agropec. 27: 87-98.

Cruz CD (2006). Programa Genes Versão Windows. Aplicativo Computacional em Genética e Estatística. UFV, Viçosa.

Cruz CD and Carneiro PCS (2003). Modelos Biométricos Aplicados ao Melhoramento Genético. UFV, Viçosa.

Fehr WR (1987). Principles of Cultivar Development: Theory and Technique. MacMillan, New York.

Ferrão LFV, Cecon PR, Finger FL, Silva FF, et al. (2011). Divergência genética entre genótipos de pimenta com base em caracteres morfo-agrônomicos. Hortic. Bras. 29: 354-358.

Ferreira CF, Pereira MG, Santos AS, Rodrigues R, et al. (2003). Resistance to common bacterial blight in Phaseolus vulgaris L. recombinant inbred lines under natural infection of Xanthomonas axonopodis pv. phaseoli. Euphytica 134: 43-46.

Ferreira CF, Pereira MG, Santos AS, Rodrigues R, et al. (2004). Xanthomonas axonopodis pv. phaseoli resistance in common bean (Phaseolus vulgaris L.) recombinant inbred lines. Crop Breed. Appl. Biotechnol. 4: 100-104.

Gioria R, Braga RS, Krause-Sakate R, Roullier C, et al. (2009). Breakdown of resistance in sweet pepper against Pepper yellow mosaic virus in Brazil. Sci. Agric. 66: 267-269.

Gonçalves LSA, Rodrigues R, Bento CS, Robaina RR, et al. (2011). Herança de caracteres relacionados à produção de frutos em Capsicum baccatum var. pendulum com base em análise dialélica de Hayman. Ver. Ciênc. Agron. 42: $662-669$.

Grub RC, Blauth JR, Arnedo Andrés MS, Caranta C, et al. (2000). Identification and comparative mapping of a dominant potyvirus resistance gene cluster in Capsicum. Theor. Appl. Genet. 101: 852-859.

Inoue-Nagata AK, Fonseca ME, Resende RO, Boiteux LS, et al. (2002). Pepper yellow mosaic virus, a new potyvirus in sweetpepper, Capsicum annuum. Arch. Virol. 147: 849-855.

Janzac B, Fabre MF, Palloix A and Moury B (2009). Blackwell Publishing Ltd. Phenotype and spectrum of action of the Pvr4 resistance in pepper against potyviruses, and selection for virulent variants. Plant Pathol. 58: 443-449.

Juhász ACP, Silva DJH, Zerbini FM Jr, Carneiro PCS, et al. (2008). Base genética da resistência de um acesso de tomate silvestre ao mosaico-amarelo do pimentão. Pesq. Agropec. Bras. 43: 713-720.

Lobo VLS, Giordano LB and Lopes CA (2005). Herança da resistência à mancha-bacteriana em tomateiro. Fitopatol. Bras. 30: 343-349.

Maciel-Zambolim E, Costa H, Capucho AS, Avia AC, et al. (2004). Surto epidemiológico do vírus do mosaico amarelo do pimentão em tomateiro na região serrana do Espírito Santo. Fitopatol. Bras. 29: 325-327.

Mather K and Jinks LL (1984). Introdução à Genética Biométrica. Sociedade Brasileira de Genética, Ribeirão Preto.

Moscone EA, Scaldaferro MA, Grabiele M, Cecchini NM, et al. (2007). The evolution of chili peppers (Capsicum Solanaceae): a cytogenetic perspective. Acta Hortic. 745: 137-170.

Moura MCCL, Gonçalves LSA, Sudré CP, Rodrigues R, et al. (2010). Algoritmo de Gower na estimativa da divergência 
genética em germoplasma de pimenta. Hortic. Bras. 28: 155-161.

Moura MF, Mituti T, Marubayashi JM, Gioria R, et al. (2011). A classification of Pepper yellow mosaic virus isolates into pathotypes. Eur. J. Plant Pathol. 131: 549-552.

Nascimento IR, Valle LAC, Maluf WR, Gonçalves LD, et al. (2007). Reação de híbridos, linhagens e progênies de pimentão à requeima causada por Phytophthora capsici e ao mosaico amarelo causado por Pepper yellow mosaic virus (PepYMV). Ciênc. Agrotec. 31: 121-128.

Pickersgill B (1997). Genetic resources and breeding of Capsicum spp. Euphytica 96: 129-133.

Ramalho MAP, Santos JB and Zimmermann MJ (1993). Genética Quantitativa em Plantas Autógamas: Aplicações ao Melhoramento do Feijoeiro. UFG, Goiânia.

Rêgo ER, Rêgo MM, Cruz CD, Finger FL, et al. (2011). Phenotypic diversity, correlation and importance of variables for fruit quality and yield traits in Brazilian peppers (Capsicum baccatum). Genet. Res. Crop. Evol. 58: 909-918.

Riva EM, Rodrigues R, Pereira MG, Sudré CP, et al. (2004). Inheritance of bacterial spot disease in Capsicum annuum L. Crop Breed. Appl. Biotechnol. 4: 490-494.

Sudré CP, Goncalves LS, Rodrigues R, do Amaral Junior AT, et al. (2010). Genetic variability in domesticated Capsicum spp as assessed by morphological and agronomic data in mixed statistical analysis. Genet. Mol. Res. 9: 283-294.

Truta AAC, Souza ARR, Nascimento AVS, Pereira RC, et al. (2004). Identidade e propriedades de isolados de Potyvirus de Capsicum spp. Fitopatol. Bras. 29: 160-168.

Xu Y, Kang D, Shi Z, Shen H, et al. (2004). Inheritance of resistance to zucchini yellow mosaic virus and watermelon mosaic virus in watermelon. J. Hered. 95: 498-502.

Zimmer AR, Leonardi B, Miron D, Schapoval E, et al. (2012). Antioxidant and anti-inflammatory properties of Capsicum baccatum: from traditional use to scientific approach. J. Ethnopharmacol. 139: 228-233. 